\author{
Journal of Social Economics Research \\ 2022 Vol. 9, No. 1, pp. 27-38. \\ $\operatorname{ISSN}(e): 2312-6264$ \\ $\operatorname{ISSN}(p): 2312-6329$ \\ DOI: $10.18488 / 35 . v 9 i 1.2909$ \\ (C) 2022 Conscientia Beam. All Rights Reserved. \\ check for
updates
}

\title{
DETERMINANTS OF SOCIAL SECURITY FINANCING IN ALGERIA: A MARKETING APPROACH USING A LOGIT MODEL
}

\section{Nassima Guellil ${ }^{1}$ \\ Abderrezzak \\ Benhabib $^{2+}$}

\author{
${ }^{1,2}$ Tlemcen University, Algeria. \\ Email: guellilnassima@yahoo.fr \\ Email:abenhabib1@yahoo.fr.Tel:+213553310443
}

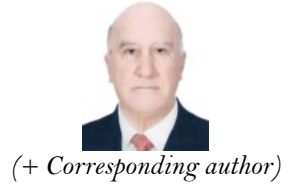

ABSTRACT
Article History

Received: 2 August 2021 Revised: 15 December 2021 Accepted: 28 December 2021 Published: 18 January 2022

\section{Keywords}

Social security

Financing

Social contributions.

JEL Classification: H55, I13, C50, M31.

\begin{abstract}
Social security is an important tool aimed at ensuring the social protection of individuals against social risks. However, almost all countries face problems linked to social security financing because their resources are insufficient to cover their expenses. This funding problem is related to the efficiency in the collection of contributions, as the contribution of the working population to the financing of social security can ensure its sustainability. Although social security is mandatory, the absence of funding participation by many people in Algeria contributes to a deepening of the funding crisis. This study aims, first, to examine the extent to which the employed population can finance Algerian social security and, second, to uncover the factors that cause the private sector to refrain from participating in the financing of social security in Tlemcen. Our methodology draws on a marketing approach using the logit model, which reveals that three types of factors have the greatest influence on the participation of individuals in the financing of social security: socio-economic factors, individual characteristics, and the regulation system adopted by the Algerian Social Security Institution.
\end{abstract}

Contribution/Originality: This study is one of very few that has investigated social security using a marketing approach. The logistic model allowed us to demonstrate that participation in the financing of social security is due to individual, behavioral and institutional reasons.

\section{INTRODUCTION}

Social security plays a major role in protecting members of society from various social hazards that cause income interruption, such as sickness, maternity, accidents and occupational diseases, unemployment, disability, retirement and death. Many organizations are concerned with the issue of social security, including the International Labor Organization, International Society for Social Security, and International Labor Conference.

Social security faces a long-term financing gap, meaning that it is reaching a state of fiscal imbalance (Johnson, 2020) as longer lifespans and declining fertility are reducing the number of workers supporting an ageing population. The Social Security actuaries' intermediate projections of 2019 show that, under the current rules, the combined trust funds will run out in 2035, after which the system will be able to pay only about four-fifths of scheduled benefits (Johnson, 2020). Many authors have studied social security deficits. Chomik, John, Alan, George, and Cagri (2016) applied an econometric model to study the economic effects of the reform of social security systems. Soares and Bloch (2019) sought to estimate the distributive impact of taxes and other fiscal contributions that finance social security in Brazil. They used concentration coefficients computed by Silviera Passos, weighted by 
the relative contribution of each tax to funding social security (by distinguishing individual social security contributions from taxes collected by the states and the Union). In the search for the main vectors that may improve the financing of the social security budget in Ukraine, Rippa (2018) proposed, first, a decentralization of the financing of social protection and social security, and second, an optimization of the state policy on the labor market with a view to its rapid adaptation to the structural changes taking place in the economy since the social-market economy is aimed not only at social protection, but also at the creation of an organizational and economic mechanism that can contribute to reducing the portion of the population that needs state paternalistic care (social assistance). Schieber's (2017) analysis explored the generational equity of potential social security reforms and argued for an inclusion of all generations in bringing the system's financing back into balance as soon as possible. On the basis of prior studies that examined the aging societies of Australia and America, Ben Othman (2015) described the economic effects of pension systems in Tunisia through the use of a general equilibrium model computed across overlapping generations. His results suggest that a reduction of the pension system deficit would require, in addition to an increase in citizens' participation and a reduction of subsidies, a shift in the retirement age and a change towards the capitalization system. Imorohoroglu and Sagiri (2012) applied the general quantitative equilibrium model for interlocking generations to study the impact of reforms on the US social security system. Their study showed that policies play an effective role in promoting the participation of the elderly workforce, whose participation is essential to the sustainability of the system. Tshichart (2006) developed a model to solve the problem of the financial sustainability of social security in America that would ensure the safety of the social security system for at least 75 years. Luttmer and Andrew (2015) studied the impact of the policy of uncertainty (associated with social security) on individual welfare. There are also some studies concerned with the analysis of the demand for certain types of insurance. In this regard, Fontaine, Plisson, and Zirrar (2014) used the logit and probit models to analyze, through a questionnaire, risk perception and the demand for dependency insurance.

As far as Algerian studies are concerned, some authors like Kaddar (1988) have examined the issue of social security financing in connection with the employment situation and the independence of public institutions. Another study conducted by Salhi (2015) focused on the search for ways to reform the Algerian pension system, while Labair, Graa, and Azzine (2017) presented an analysis of the quality of services provided by social security institutions. Moreover, Hammouda and Merouani (2015) applied a multidimensional interpolation analysis to demographic developments linked to the pension system in Algeria. Previous researchers have not paid attention to the study of social security on an individual basis, aside from Merouani and Hammouda (2013) and Merouani, Hammouda, and EL Mouden (2016), who studied the reasons for the lack of coverage due to the behavior of private sector agents outside the agricultural sector.

Thus, most studies that deal with social security have addressed its deficit from a macro-socio-economic perspective. This approach cannot encompass both the main factors that underpin the deficit as well as the method of dealing with the associated factors. Our study focuses on the social security deficit caused by a lack of revenues stemming from insufficient contributions of individuals working in the private sector. Thus, we will try to identify the reasons that motivate or prevent them from participating in social security financing, knowing that raising the level of contributions contributes to solving the problem of social security financing and ensuring its sustainability.

So, our study deals with the contribution of individuals to the financing of social security by investigating the following question: What are the reasons behind the acceptance or reluctance of private sector individuals to participate in the financing of social security? Accordingly, we hypothesize that participation in the financing of social security is due to individual, behavioral and institutional reasons.

To answer this research question we will first draw on Algerian social security facts. After that, we present the factors that influence the participation in social security financing: individual and behavioral factors in addition to institutional factors (social security services). 


\section{DEFINITION OF SOCIAL SECURITY}

The Cambridge Dictionary defines social security as "an official institution that brings together a number of administrative bodies that aim to protect citizens against the consequences of accidents or situations characterized by social dangers, offering them the lowest guarantees to bear the burden of the consequences of these social risks (sickness, maternity, work accidents, disability ... ) based on national solidarity, which makes compulsory public social security for all workers regardless of the nature of their employment contracts. "

Social security is a tool that enables the state to protect the members of society against the social risks they face that can cause low income (disability, retirement), or rising expenses (treatment, children). The state guarantees a basic income for individuals allowed to live in the midst of their community (Nassima, Benchaib, \& Aicha, 2017).

\section{SOURCES OF SOCIAL SECURITY FINANCING}

The sources of social security financing include contributions, the state budget, as well as other resources.

- Contributions: These are compulsory for wage earners and employers and are the main source of social security financing. Schemes based on social contributions continue to play a central role in the development of comprehensive national social protection systems. The substantial share of social contributions in total social protection expenditure shows its critical role in financing social security (ILO, 2018).

- State Budget: To reduce the burden on contributions, the State intervenes through its budget to contribute to the financing of social security.

- Other resources: These include increases in delays and penalties as well as income from the Social Security funds.

\section{THE REALITY OF SOCIAL SECURITY IN ALGERIA}

Starting in 2000, the Algerian social security sector launched an ambitious reform program to improve the quality of its performance, modernize the social security system and maintain the financial balance of the system.

Since 2015 , faced with the deteriorating financial position of the country following the decline in oil windfalls, fears have begun to loom over the financial future of social security system that have prompted the authorities to search for new mechanisms to maintain the financial balance of social security. The objective has been to reform the funding system through health expenditure rationalization and develop mechanisms to collect contributions by expanding social coverage to include informal groups of traders, farmers, and handcraft workers.

\subsection{Reform}

Reform of mechanisms for the collection of social security contributions have been made through friendly social security settlement facilities for employers (schedule for debt repayment and exemption from delay penalties, exceptional procedures applied until 31 March 2016, under the Finance Act 2015) to ease the forced collection of contributions from employers who do not respond to official notices, and to tighten financial penalties in case of failure to report their employees.

In 2013, the number of subscribers was estimated at $550 \mathrm{000}$, distributed across 13 regional agencies covered 49 agencies, and the state directorates were mandated to expand coverage by opening 135 desk-registers within 4 months. Moreover, in order to increase contributions, even though the Fund completely abolished penalties, it remains the case that after 2015, 1.5 million subscribers have still not paid their contributions. The Social Security Fund for non-employees managed to collect 23 billion DA, or 58 percent of the expected contributions, after 300 ooo non-wage workers settled their situation since the start of the reform.

In addition, the General Tax Directorate has granted tax exemptions to self-employed workers. Their contributions are deducted from the taxes imposed on them in addition to enabling them to raise their pension 
contributions and choose the best 10 years in terms of contribution. The program allowed 91,000 employers to pay 36 billion DA as their contribution to the fund, though the employers reported 15840 wages that were registered for social security services, allowing them to benefit from social coverage. With regard to the voluntary registration within the social security system of individuals without social coverage, their number exceeded 9056 persons with a transition period of 3 years for the payment of a monthly subscription of 2160 DA with the possibility of benefiting from an old age pension once they are integrated into the formal sector.

\subsection{System's Funding}

Reforming the system's funding through the creation of additional resources other than those related to labor income contributions (National Pension Reserves - National Social Security Fund).

\section{FACTORS THAT DETERMINE PARTICIPATION IN SOCIAL SECURITY FINANCING}

There are several factors that may explain the willingness of individuals to participate in the financing of social security, including those related to the individual, to his behavior, as well as to the social security administration.

\subsection{Factors Related to the Individual}

- Age is a variable that affects attitudes towards insurance services, though Pooja \& Gaurav (2012) found that age did not have a significant effect on the acquisition of life insurance services.

- Gender: Studies indicate that when gender is used as a variable there are different results for men and women in terms of social security. Some authors (e.g., Outreville, 2014) argue that women are more at risk than men. While some studies have found that women having a higher involvement in social security than men (Auerbach, Genoni, \& Pages, 2007) due to their stronger preference for saving, their longer life expectancy and their complementary income to their husbands (Huberman, Sheena, \& Wei, 2007), women are represented in retirement plans at a rate of 6.5 percent more than men and contribute nearly $\$ 500$ more than men. Women are therefore more likely to participate in plans that defer current consumption to the future. The family structure plays a major role in determining demand for social security. Marriage changes the behavioral decisions of individuals. The spouses' earnings may become complementary to each other, i.e., the present may be preferred by one partner and the future by the other, where the probability of participation is higher among unmarried women. As for men, the probability of participation in social security increases when they are married. In this case, the man becomes the head of the household and has responsibilities towards his wife, especially if the wife does not work and does not make any social security contributions.

- Education enables individuals to change society for the better. The level of education may lead to increased awareness of the need for insurance. Insurance leads to a high risk perception ratio and several papers have found a positive relationship between the level of education and demand for insurance (Brown, Zoran, \& Weisbenner, 2013; Merouani et al., 2016; Outreville, 2014). As social security contributions protect against social hazards, awareness of the danger is greater in those who are more educated (Hussel, Demian, \& Ralf, 2005).

\subsubsection{Income and Health}

Income and health both positively affect an individual's ability to pay social security contributions. Aguibou (2014), in his study of social protection in Senegal, found that low-income earners do not receive insurance, but only those who earn at least 5 times the guaranteed minimum income, more than 275 euros. Workers are some of the most important financiers of health, but their income is low. They cannot afford insurance or to pay for health coverage, which leads them to resort to public health structures and pay lower costs. 


\subsubsection{Occupation}

Demand for insurance services is strongly linked to the occupations of community members and to the size of the enterprise. Often, in very small businesses, employers hesitate to insure their workers, although the riskiness of the work may determine individuals' access to social security. However, in some other cases, the employees remain deprived of many rights, such as compensation for illness and retirement. The size of the business for which individuals work may thus affect their access to social security. Workers in large businesses contribute more to social security (Auerbach et al., 2007). To all these variables, we can also add Social Status and the Number of Children.

\subsection{Behavioral Variables}

\subsubsection{Risk Aversion}

Many studies have focused on the relationship between risk aversion and insurance demand, including Kouame and Komenan (2012); Outreville (2015); Outreville (2014); Fontaine and Nina (2013); Merouani et al. (2016). They all recognize that risk drives individuals to participate in social security as it offers the option of preventing risk, not just as an organizational choice but beyond that as a moral and a human choice. Risk avoidance is also linked to employment and the quality of the job, where wage earners are more risk averse than employers and liberals (Cramer, Hartog, Jonker, \& Van Praag, 2002). Workers in large enterprises also contribute more to social security than workers in small enterprises. Social security may help individuals reduce the uncertainties related to health expenses (Merouani et al., 2016).

\subsubsection{Preference}

Preference for the Present refers to a lack of care for the future. The attempt to hedge against future risks may cause reduced demand for social security, especially in young people who avoid thinking about retirement (Romeo and Nina, 2013).

\subsubsection{Knowledge}

Social security involvement requires that the insured individual be aware of the existence and performance of social security services. Several studies have shown a positive relationship between social security participation and access to information on the services it provides to beneficiaries (Aguibou, 2014); (Fontaine \& Nina, 2013). Aguibou (2014) studied social protection in Senegal and found that less than half of the population is aware of social security (46 percent). For example, construction workers have little knowledge of social security, which makes them resort to public health structures during illness or after professional accidents (Aguibou, 2014). Knowledge of social security is connected with several other factors such as education, number of children, the professional status of the worker and the size of the institution. The higher individuals' level of knowledge and understanding of social security, the greater their desire to participate (Merouani, Hammouda, \& Claire, 2017).

\subsubsection{Religious Beliefs}

It was once believed that a positive attitude towards insurance could be explained by a lack of belief in God. This would make religious people express less demand for social insurance. But according to Najmul (2008), social security must be a means to an end as it seeks to establish a society based on economic and social justice. Ibrahim (2010) stated that compulsory social insurance is not haraam (forbidden by religion).

\subsubsection{Trust}

Individuals' confidence in the government makes them trust in their governmental institutions. Since the Algerian Social Security is a public institution, financed by the contributions of workers and employers and 
government budget, the confidence individuals have in this institution is a key factor in their contribution to social security financing. The degree of confidence is a variable that affects social insurance demand (Brown et al., 2013). A lack of trust limits the demand for insurance (Platteau, De Bock, \& Gelade, 2017).

\subsubsection{Altruism}

The altruistic consideration is based on the provision of social security advantages to other individuals, such as family members. Once the worker has paid his social security contributions, his rights to social protection cover his children and wife as well.

\subsection{Factors Related to Social Security}

These variables include the rules of law relating to social security and also the services provided by the social security administration.

\subsubsection{Legislation}

Clear and simple procedures make it easier to participate in and act responsibly towards social security, while complex procedures may further alienate participants. In a study on employers' responsibility for the financing of occupational diseases in France, employers' reluctance to assume the burden of professional effects on their workers is explained by the complex procedures faced by employers during the recognition of occupational diseases (Durant, 2016).

\subsubsection{Quality of Services Provided by Social Security}

Quality service can be confirmed only when the service is made available to the customer. Quality service is a judgment expressed by a satisfied customer within a particular situation (Outreville, 2015).

\section{METHODOLOGICAL RESEARCH FRAMEWORK}

The research variables can be summarized in a theoretical model which is represented in Figure 1.

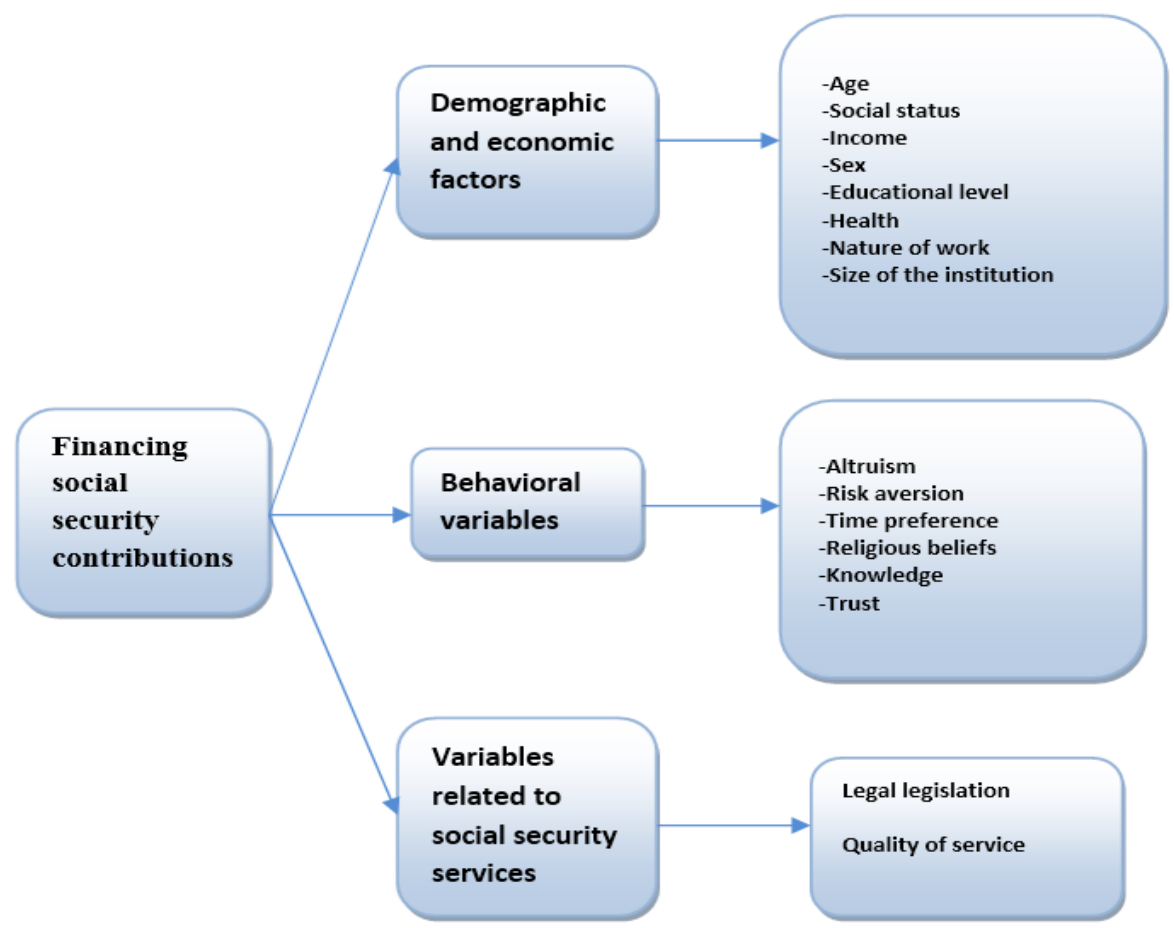

Figure 1. Variables affecting participation in social security financing. 


\subsection{Conceptual Model}

To analyze the data, we used SPSS 23. To test the hypotheses and the theoretical model, we used EViews as a working method applied to the logistic model.

\subsection{Description of the Sample}

The empirical study focused on the private sector as the group most likely to evade payment of social security contributions. The sample of the study includes 358 representative individuals, covering the five main categories: agriculture, trade, industry, construction, and services. The field survey took about 3 months, spanning the period from December $14^{\text {th }} 2017$ to March $15^{\text {th }} 2018$.

To assess the validity of the study, we proceeded to test the reliability of the questionnaire through the use of the Alpha-Cronbach coefficient, which gave an acceptable value of 0.872 .

\subsection{Analytical Study}

The analytical study was carried out in SPSS 23, which enabled us to obtain the tables below.

\subsection{Participation in Social Security}

Although social security is mandatory for all working groups, not only in the public but also in the private sector, only $55 \%$ of the sample participated in social security financing. Table 1 illustrates that participation in social security may vary from sector to sector.

Table 1. Distribution of society by sector and participation in social security.

\begin{tabular}{|c|c|c|c|c|c|c|c|}
\hline \multirow[t]{2}{*}{ Total } & \multicolumn{6}{|c|}{ Sectors } & \\
\hline & Industry & Trade & Construction & Agriculture & Services & Others & \\
\hline Yes & 10 & 43 & 23 & 57 & 35 & 29 & 197 \\
\hline No & 11 & 50 & 11 & 66 & 11 & 12 & 161 \\
\hline
\end{tabular}

The lack of participation in social security is most pronounced in the agricultural and trade sectors. The insurance shortage is almost equally distributed in the services, industry, and construction sectors. Insurance covers less than half the sample in the industry, despite the many dangers inherent in this sector. Nonetheless, it exhibits a lack of coverage, whereas in the construction sector the number of contributors is twice the number of noncontributors

In order to answer the research question and test the hypotheses, we used the logit regression model.

\subsection{The Logit Regression Model}

In order to extract the relationships between the dependent variable and the different variables, we used the logit regression model. Our objective is to discover which variables influence individuals' participation in social security financing. In this case, we focused on the probability of participating or not. In the logit regression model, the anticipated values of the dependent variable should never be equal to or less than zero or, conversely, equal to or more than one, whatever the values of the independent variables. These characteristics can be denoted as:

$$
P\left(B_{i} X_{i}\right)=\exp \left(B_{i} X_{i}\right) /\left[1+\left(B_{i} X_{i}\right)\right]
$$

And the test of the model consists of the application of the likelihood function.

$$
\operatorname{Logit}\left(P_{i}\right)=\operatorname{Ln}\left(P_{i} / 1-P_{i}\right)=e B_{i}
$$




$$
\operatorname{Ln}\left(P_{i} / 1-P_{i}\right)=B_{0}+B_{1} X_{1}+\ldots \ldots \ldots+B_{n} X_{n}+R
$$

Where

$P_{i}$ : Is the probability of social security participation.

$B_{0}, B_{i}$ : coefficients.

$X_{i}$ : Various explanatory variables.

$R$ : Residuals

\subsubsection{Test of the Significance of the Variables}

Table 2 presents the various variables we selected in the first stage. Each variable was tested individually. If the statistical probability of the Z-statistic is more than $5 \%$, the coefficient is not significant and is therefore rejected, but if it is smaller than $5 \%$ it is significant and accepted.

Table 2. Significance of the variables.

Dependent Variable: ASS

Method: ML - BinaryLogit (Newton-Raphson / Marquardtsteps)

\begin{tabular}{|c|c|c|c|c|}
\hline Variable & Coefficient & Std. Error & z-Statistic & Prob. \\
\hline $\mathrm{AGE}$ & 0.719 & 0.296 & 2.423 & 0.015 \\
\hline SEXE & 1.428 & 0.748 & 1.908 & 0.056 \\
\hline $\mathrm{SM}$ & -0.787 & 0.631 & -1.246 & 0.212 \\
\hline $\mathrm{NE}$ & 0.112 & 0.157 & 0.716 & 0.473 \\
\hline EDU & 0.653 & 0.225 & 2.902 & 0.003 \\
\hline $\mathrm{R}$ & 0.511 & 0.208 & 2.451 & 0.014 \\
\hline $\mathrm{T}$ & 0.347 & 0.225 & 1.541 & 0.123 \\
\hline SO & 2.939 & 1.148 & 2.558 & 0.010 \\
\hline ALT & 0.166 & 0.181 & 0.920 & 0.357 \\
\hline RISQ & 0.263 & 0.192 & 1.366 & 0.171 \\
\hline $\mathrm{PT}$ & 0.355 & 0.177 & 2.007 & 0.044 \\
\hline $\mathrm{ES}$ & -0.142 & 0.298 & -0.478 & 0.632 \\
\hline $\mathrm{MC}$ & 0.961 & 0.584 & 1.644 & 0.100 \\
\hline $\mathrm{EV}$ & -0.485 & 0.203 & -2.384 & 0.017 \\
\hline RELIGION & 0.085 & 0.242 & 0.352 & 0.724 \\
\hline KNOWLEDGE & 0.493 & 0.264 & 1.865 & 0.062 \\
\hline $\mathrm{CONF}$ & 0.201 & 0.263 & 0.763 & 0.445 \\
\hline REGL & 0.530 & 0.558 & 0.950 & 0.341 \\
\hline NREGL & 0.129 & 0.553 & 0.233 & 0.815 \\
\hline QS & -0.003 & 0.315 & -0.011 & 0.991 \\
\hline RSS & 0.074 & 0.349 & 0.212 & 0.832 \\
\hline $\mathrm{C}$ & -16.089 & 3.062 & -5.253 & 0.000 \\
\hline McFadden R-squared & 0.466 & \multicolumn{2}{|c|}{ Mean dependent var } & 0.595 \\
\hline S.D. dependent var & 0.492 & \multicolumn{2}{|c|}{ S.E. of regression } & 0.365 \\
\hline Akaike info criterion & 0.959 & \multicolumn{2}{|c|}{ Sum squared resid } & 21.479 \\
\hline Schwarz criterion & 1.345 & \multicolumn{2}{|c|}{ Log likelihood } & -65.817 \\
\hline Hannan-Quinn criter. & 1.116 & \multicolumn{2}{|c|}{ Deviance } & 131.635 \\
\hline Restr. deviance & 246.956 & \multicolumn{2}{|c|}{ Restr. log likelihood } & -123.478 \\
\hline LR statistic & 115.320 & \multicolumn{2}{|c|}{ Avg. log likelihood } & -0.359 \\
\hline Prob(LR statistic) & 0.000 & & & \\
\hline ObswithDep=0 & 74 & \multicolumn{2}{|c|}{ Total obs } & 183 \\
\hline ObswithDep $=1$ & 109 & & & \\
\hline
\end{tabular}

The test helped us eliminate the variables that are not significant as shown in Table 2, such as marital status with a probability of 0.21 , number of individuals in the family (0.47), altruism (0.35), risk aversion (0.17), religious belief (0.72), and confidence (0.44). Then, we retained only the variables that are significant, as shown in Table 3. 
Table 3. Estimation Results.

\begin{tabular}{|c|c|c|c|c|}
\hline \multicolumn{5}{|c|}{$\begin{array}{l}\text { Dependent Variable: ASS. } \\
\text { Method: ML - Binary Logit (Newton-Raphson / Marquardt steps) }\end{array}$} \\
\hline Variable & Coefficient & Std. Error & z-Statistic & Prob. \\
\hline$\overline{\mathrm{AGE}}$ & 0.574 & 0.137 & 4.188 & 0.000 \\
\hline EDU & 0.656 & 0.125 & 5.233 & 0.000 \\
\hline $\mathrm{R}$ & 0.491 & 0.136 & 3.606 & 0.0003 \\
\hline $\mathrm{T}$ & 0.533 & 0.114 & 4.692 & 0.000 \\
\hline $\mathrm{SO}$ & 1.162 & 0.361 & 3.223 & 0.001 \\
\hline $\mathrm{PT}$ & 0.247 & 0.089 & 2.761 & 0.006 \\
\hline $\mathrm{MC}$ & 0.502 & 0.252 & 1.991 & 0.046 \\
\hline REGL & 0.325 & 0.127 & 2.559 & 0.011 \\
\hline $\mathrm{C}$ & -9.999 & 1.218 & -8.213 & 0.000 \\
\hline McFadden R-squared & 0.277 & \multicolumn{2}{|c|}{ Mean dependent var } & 0.551 \\
\hline S.D. dependent var & 0.498 & \multicolumn{2}{|c|}{ S.E. of regression } & 0.407 \\
\hline Akaike info criterion & 1.045 & \multicolumn{2}{|c|}{ Sum squared resid } & 57.906 \\
\hline Schwarz criterion & 1.142 & \multicolumn{2}{|c|}{ Log likelihood } & -178.017 \\
\hline Hannan-Quinn criter. & 1.083 & \multicolumn{2}{|c|}{ Deviance } & 356.036 \\
\hline Restr. deviance & 492.667 & \multicolumn{2}{|c|}{ Restr. log likelihood } & -246.334 \\
\hline LR statistic & 136.631 & \multicolumn{2}{|c|}{ Avg. log likelihood } & -0.497 \\
\hline Prob(LR statistic) & 0.000 & & & \\
\hline ObswithDep=0 & 161 & \multicolumn{2}{|c|}{ Total obs } & 358 \\
\hline ObswithDep=1 & 197 & & & \\
\hline
\end{tabular}

The first hypothesis: Sociodemographic variables that affect an individual's impulse to participate in social security include age, educational level, income, health, size of the institution and nature of the work; however, gender and social status are rejected.

The second hypothesis: The only behavioral variable shown to affect individuals' impulse to pay social security contributions is temporal preference. Risk aversion, altruism, religious beliefs, knowledge, and trust in social security are not significant.

The third hypothesis, that individuals' contributions to social security are linked to the social security services themselves, is accepted for legal legislation and rejected for new laws and quality of service.

The logistic regression equation demonstrates the variables that positively affect participation in social security. These are age, level of education, income, nature of work, size of the institution, time preference and social security services. Table 4 shows that there is a positive relationship between almost all the independent variables and the dependent variable; i.e., whenever there is an increase of one degree at the age level, the chance of individuals participating in social security jumps by 1.55 ; when the size of the institution gains one unit, the probability of participation in social security goes up by 2.98, almost 3 times; whenever there is a change of one unit in time preference, the participation in social security increases by 1.22; and if the incidence of sickness increases, the probability of participating in social security is about 1.92, almost double. Finally, if there were a one-step improvement in legal procedures, the participation in social security funding would increase by 1.5 .

The effect of the educational level on participation in social security shows that individuals with a university education participate in social security at a rate of 5.07 more than individuals below that educational level, and for those who have had the opportunity to participate in vocational training it is 37.37 times higher.

We also found that the participation in social security of those whose income is between 36000 DA and 45000 DA is 11.7 times greater than that of those with an income of less than 18000 DA, and more than 20,369 if the income is between $54000 \mathrm{DA}$ and $90000 \mathrm{DA}$.

As for the variable nature of work, permanent employees are 6.36 times more likely to participate in the financing of social security than temporary employees. 
Table 4. Parameters of model variables.

\begin{tabular}{|c|c|c|}
\hline Variable & B & $\operatorname{Exp}(B)$ \\
\hline Age & 0.439 & 1.551 \\
\hline \multicolumn{3}{|l|}{ Education } \\
\hline Education (1) & -0.702 & 0.496 \\
\hline Education (2) & -1.765 & 0.465 \\
\hline Education (3) & 0.786 & 2.194 \\
\hline Education (4) & 1.621 & 5.070 \\
\hline Education (5) & 3.621 & 37.379 \\
\hline Income $(\mathrm{R})$ & 1.244 & \\
\hline Income (1) & 2.46 & 3.470 \\
\hline Income (2) & 3.014 & 11.703 \\
\hline Income (3) & 0.257 & 20.369 \\
\hline Income (4) & & 1.294 \\
\hline \multicolumn{3}{|l|}{ Nature of work } \\
\hline work (1) & 0.210 & 1.234 \\
\hline work (2) & 1.851 & 6.365 \\
\hline work (3) & 1.277 & 3.586 \\
\hline $\begin{array}{l}\text { Size of } \\
\text { Enterprise }\end{array}$ & 1.093 & 2.983 \\
\hline Time preference & 0.204 & 1.226 \\
\hline Sickness & 0.653 & 1.921 \\
\hline Legal procedures & 0.407 & 1.502 \\
\hline
\end{tabular}

\section{CONCLUSION}

The most influential factors on the contribution of the private sector to social security financing are socioeconomic and demographic factors such as age, income, education, size of the institution where they work, and nature of the performed work. Among the behavioral variables, time preference is the best determinant of participation in social security. Regarding the factors related to social security, we found that individuals are affected only by legal procedures, while the quality of social security services such as the speed of services and the value of compensation does not play a role. Although individual participation is expensive, it remains the fact that any contributor can be compensated through the offered protection from social hazards to which he may be exposed.

To conclude our work, we can say that individuals still perceive mandatory deductions as negative, which causes them to opt to keep money in their possession instead of providing it to the social security institution for protection, without thoroughly considering social security variables.

\subsection{Policy Implications}

Social security institutions should design and implement a comprehensive communication policy towards private sector workers.

Funding: This study received no specific financial support.

Competing Interests: The authors declare that they have no competing interests.

Authors' Contributions: Both authors contributed equally to the conception and design of the study.

\section{REFERENCES}

Aguibou, M. D. (2014). Social protection in Senegal, the example of construction workers in Dakar. Doctoral Thesis, University of Western Brittany.

Auerbach, P., Genoni, M. E., \& Pages, C. (2007). Social security coverage and the labor market in developing countries. IZA

Discussion Paper N 2979. 
Ben Othman, M. (2015). The macroeconomic effects of pension systems: Reform simulation for Tunisia. Doctoral Thesis in Economics and Finance, University of Nice.

Brown, J., Zoran, I., \& Weisbenner, S. J. (2013). Empirical determinants of intertemporal choice (February 2013). NBER WorkingPaper No. w 18755

Chomik, R., John, P., Alan, D. W., George, R., \& Cagri, K. (2016). Means testing social security: Modeling and policy analysis. Ann Arbor, MI. University of Michigan Retirement Research Center (MRRC) Working Paper, WP 2016-337.

Cramer, J. S., Hartog, J., Jonker, N., \& Van Praag, C. M. (2002). Low risk aversion encourages the choice for entrepreneurship: An empirical test of a truism. Journal of Economic Behavior \& Organization, 48(1), 29-36. Available at: https://doi.org/10.1016/s0167-2681(01)00222-0.

Durant, C. N. F. (2016). Employers' liability and financing of occupational diseases; TRACKS reviews. Retrieved from: www.pistes.revues.org

Fontaine, R., \& Nina, Z. (2013). How to explain the low willingness of individuals to cover themselves against the risk of dependency? A review of the literature, health economics issues. Retrieved from www.irdes.fr.

Fontaine, R., Plisson, M., \& Zirrar, N. (2014). To what extent do individual preferences constrain the development of the longterm care insurance market. Economics and Statistics, $\mathrm{n}^{\circ} 1$.

Hammouda, N. E., \& Merouani, W. (2015). Demography and the Algerian retirement system. The Company, 4(1), 21-38.

Huberman, G., Sheena, S. I., \& Wei, J. (2007). Defined contribution pension plan: Determinants of participation and contributions rates (pp. 32): Springer, Science.

Hussel, S., Demian, W., \& Ralf, Z. (2005). Stimulating the demand for insurance. Risk Management and Insurance Review, 8(2), 257-278. Available at: https://doi.org/10.1111/j.1540-6296.2005.00059.x.

Ibrahim, S. I. (2010). Insurance and social security, investment and sustainable environment, a study in the role of Zakat in the development of society (1st ed., pp. 246). Cairo: Modern Book House.

ILO. (2018). Financing social protection for the future of work: Fiscal aspects and policy options. Retrieved from www.ilo.org.

Imorohoroglu, S., \& Sagiri, K. (2012). Social security, benefit claining and labour force participation, a quantitative general equilibrum approch. American Economic Forme Macroeconomics, 4(3), 96-127.

Johnson, R. W. (2020). How does earnings inequality affect social security financing? Urban Institute: AARP Public Policy Institute. 10. Retrieved from: https://www.aarp.org/content/dam/aarp/ppi/2020/2005/how-does-earningsinequality-affect-social-security-financing.doi.2010.26419-26412Fppi.00104.26001.pdf.

Kaddar, M. (1988). Social security and financing constraint in Algeria: Data and current problems. CREAD Review Collection, $5(22), 61-75$.

Kouame, E., \& Komenan, A. (2012). Risk preferences and demand for insurance under price incertainly: An experimental approch for cocoa farmers in Cote D’ivoire. 30. Retrieved from: https://www.findevgateway.org/organization/ilos-impactinsurance-facility

Labair, S., Graa, A., \& Azzine, A. (2017). The effect of perceived quality on user satisfaction with regard to the public service, case of the CNAS. Algerian Journal of Economics and Management, 8(1), 22-34.

Luttmer, E. P., \& Andrew, A. S. (2015). The welfare cost of perceived policy uncertainty: Evidence from social security, national bureau of economic research, NBER Working Paper No. w2 1818. 43.

Merouani, W., \& Hammouda, N. (2013). The extension of social coverage to informal workers in Algeria. Retrieved from www.crudile.univ-paris.est.fr.

Merouani, W., Hammouda, N., \& Claire, E. M. (2017). Don't they care about their future ? Or they are just unaware of social insurance? Forward-looking and demand for social insurance in Algeria. Retrieved from www.dspace.cread.dz.

Merouani, W., Hammouda, N., \& EL Mouden, C. (2016). The new determinants of demand for social security: The case of the Algiers region for retirement and society. Retirement and Society, 73(1), 119-148. 
Najmul, H. (2008). Social security system of islam with special reference to Zakat (pp. 47). International Centre for Research in Islamic Economics King Abdulaziz University Jeddah-Saudi Arabia,Printed at King Abdulaziz University Press, Jeddah.

Nassima, G., Benchaib, N., \& Aicha, B. (2017). The problem of financing social security in Algerian, An International Refereed Semi-Annual Scientific Journal, issued by the University Center BelhadjBouchaib, AinTemouchent, Algeria, No. 5. 87101.

Outreville, F. (2015). The relationship between relative risk aversion and the level of education: A survey and implications for the demand for life insurance. Journal of Economic Surveys, Wiley Blackwell, 29(1), 97-111.

Outreville, J. F. (2014). Risk aversion, risk behavior, and demand for insurance: A survay. Journal of Insurance Issues, Western Risk and Insurance Association, 37(2), 158-186.

Platteau, J.-P., De Bock, O., \& Gelade, W. (2017). The demand for microinsurance: A literature review. World Development, Elsevier, 94(C), 139-156.

Pooja, K., \& Gaurav, P. (2012). A study of factor affecting the demand of health insurance in Punjab. Journal of Management and Science, 2(4), 1-10.

Rippa, M. (2018). Imperatives of budgetary financing of social protection and social security in Ukraine. World of Finance. https// www.researchgate.net/publication/336695785 Imperatives Of Budgetary Financing of Social Protection and Social Security In Ukraine.

Romeo, F., \& Nina, Z. (2013). How to explain the low willingness of individuals to cover themselves against the risk of dependency? A review of the literature, health economics issues. Retrieved from: www.irdes.fr.

Salhi, T. (2015). Ways of reform of the retirement system in Algeria: Towards the distinction between the attributions of the State and of social security. Doctoral Thesis in Commercial Sciences, University of Oran.

Schieber, S. J. (2017). Generational equity and Social Security financing reform. The Journal of Retirement, 5(1), 12-31. Available at: https://doi.org/10.3905/jor.2017.5.1.012.

Soares, S., \& Bloch, C. (2019). Distributive impacts of social security financing in Brazil. Discussion Paper, No. 244, Institute for Applied Economic Research (ipea), Brasília.

Tshichart, A. (2006). Developed a model to solve the problem of financial sustainability of social security in America that would ensure the safety of the social security system for at least 75 years.

The views and opinions expressed in this article are the views and opinions of the author(s). The Journal of Social Economics Research shall not be responsible or answerable for any loss, damage or liability caused in relation to/arising from the use of the content. 